\title{
ステンレス鋼の大気腐食割れに及ぼす湿度の影響
}

\author{
庄司三郎*, 大中紀之*, 古谷 保正*, 斉藤 隆** \\ *株式会社日立製作所日立研究所 \\ **株式会社日立製作所日立工場
}

\section{Effects of Relative Humidity on Atmospheric Stress \\ Corrosion Cracking of Stainless Steels}

\author{
Saburō Shōji*, Noriyuki Ohnaka*, Yasumasa Furutani* \\ and Takashi Saitō** \\ *Hitachi Research Laboratory, Hitachi Ltd. \\ **Hitachi Works, Hitachi Ltd.
}

\begin{abstract}
In order to evaluate the effect of environmental parameters on atmospheric stress corrosion cracking (SCC) of SUS 304 and $316 \mathrm{~L}$ stainless steels, SCC tests were carried out in laboratory air controlled temperature and relative humidity $(\mathrm{RH})$ environment by using U-bend specimens with the deposition of $0.5 \mathrm{~N}$ chloride solution $\left(\mathrm{NaCl}, \mathrm{MgCl}_{2}, \mathrm{CaCl}_{2}, \mathrm{ZnCl}_{2}\right)$ and synthetic sea water droplets.

SCC susceptibilities of steels strongly depend on RH and the maximum susceptibility was observed at the inherent relative humidity $\left(\mathrm{RH}_{\max }\right)$ for each chloride. The values of $\mathrm{RH}_{\max }$ were about $60,30,20$ and $10 \%$ for $\mathrm{NaCl}, \mathrm{MgCl}_{2}, \mathrm{CaCl}_{2}$ and $\mathrm{ZnCl}_{2}$ solutions respectively, corresponding to their vapor pressure of saturated solution $\left(\boldsymbol{P}_{\mathrm{sat}}\right)$, and hence, where the specimen surface is covered with a thin saturated chloride solution layer. In case of synthetic sea water, $\mathrm{RH}_{\max }$ was almost same as that of $\mathrm{MgCl}_{2}$, suggesting that $\mathrm{SCC}$ susceptibility was affected by the salt with lowest $P_{\text {sat }}$ even in minor solute composition.

The critical values of relative humidity $\left(\mathrm{RH}_{\mathrm{crit}}\right)$ below which no-SCC was observed were some what lower than $\mathrm{RH}_{\max }$, where the solution dried up. Above $\mathrm{RH}_{\max }$, the $\mathrm{SCC}$ susceptibilities decreased with increasing $\mathrm{RH}$, due to the dilution of the chloride solutions.
\end{abstract}

\section{1. 緒言}

化学プラントや発電プラント等の構造用材料として, SUS 304 等のオーステナイト系ステンレス鋼が多く用い られる。オーステナイトステンレス鋼は優れた耐食材料 であるが，塩化物を含む環境では孔食や応力腐食割れ (SCC) 等が比較的生じやすい。海に囲をれた我国では, プラント類は海岸近くに建造されることが多く, 海塩粒 子あるいはこれを含んだ雨水等により，大気側からの腐 食が発生しやすい。近年, 化学プラントの比較的低い温 度領域で, 保温材下や大気露出面での応力腐食割れ事例 が報告されている(1) 3)。

このような割れは, 海塩粒子の付着とその濃縮による

$*, * *$ 于317 茨城県日立市幸町 3 丁目 1-1 (3-1-1,

Saiwai-cho, Hitachi-shi, Ibaraki-ken, 317 Japan)
局部腐食個所と溶接による鋭敏化や残留応力あるいは構 造的な応力集中個所との組合せによって生じると考兄ら れる。保温材下での割れの環境因子に関しては, 塩化物 の濃縮や保温材の熱分解等飞ついての報告 ${ }^{1)}$ が見られる が，露出表面に塩化物が付着した際の環境因子の影響は 不明な点が多く, 大気腐食の基本的影響因子である湿度 依存性についても明白でない。

そこで，ステンレス鋼表面に海塩粒子等が付着した状 態を実験室的に模擬し，大気腐食割れの湿度依存性を調 べることにした。本報では, 塩化物として, 人工海水, 海水主成分の $\mathrm{NaCl}$, 副成分の $\mathrm{MgCl}_{2}$ の注か, 湿度依存 性の機構解明の一助とするために, より潮解性の強い塩 化物も取上げた。これらの塩化物の一定濃度の液滴を応 力付与試験片表面飞付着させ, 恒温恒湿雾囲気中で SCC 
試験を行った。試験材には, SUS 304 及び SUS 316L を 用いた。

\section{2. 実験方法}

\section{1 塩化物付着法と応力腐食割れ試験法}

実験には厚さ $2 \mathrm{~mm}$ の市販の SUS 304 及び 316L 冷 間圧延板を用いた。Table 1 は，素材の化学組成を示 す。所定の寸法に機湘加工後, トリクレンとアセトン中 で超音波洗浄し試験に用いた。試験片への応力の付与は

Table 1 Chemical compositions of materials used.

\begin{tabular}{lcccccccc}
\hline & $\mathrm{C}$ & $\mathrm{Si}$ & $\mathrm{Mn}$ & $\mathrm{P}$ & $\mathrm{S}$ & $\mathrm{Ni}$ & $\mathrm{Cr}$ & $\mathrm{Mo}$ \\
\hline SUS304 & 0.07 & 0.54 & 0.95 & 0.033 & 0.005 & 8.88 & 18.37 & \\
SUS316L & 0.023 & 0.70 & 1.54 & 0.035 & 0.002 & 11.97 & 17.85 & 2.10 \\
\hline
\end{tabular}

Uベンド法4)によった。

Uベンド試験片に塩化物を付着させるために，本報で は, 微量の塩化物溶液を試験片表面に滴下付着する方法 を用いた。この方法は, 脱脂洗浄した試験片表面に微量 の溶液を滴下すると, 半球状の液滴が乾燥過程で若干広 がり, 液膜や塩化物結晶が円形に付着することに着目し た方法である。それで，本方法を塩化物スポット法と呼 ぶことにする。本報の実験では, 滴下液量は $5 \mu 1$ とし た。 $5 \mu 1$ の塩化物溶液を滴下付着した試験片を室内で 自然乾燥すると, $\mathrm{NaCl}$ スポットには $\mathrm{NaCl} の$ 結晶が 直径 $3 \mathrm{~mm}$ の円環状にまばらに付着し, $\mathrm{MgC}_{2} 1$ 等の吸 湿性塩化物のスポットには直径 $3 \mathrm{~mm}$ の液膜が形成さ れる。人工海水スポットでは直径 $3 \mathrm{~mm}$ の液膜のとこ ろどころに $\mathrm{NaCl}$ と思われる結晶が析出する。塩化物 スポットの直径は, 種々の湿度雾囲気中で試験した後も ほとんど変わらなかった。

実験は，人工海水と海水主成分 $\mathrm{NaCl}$, 副成分 $\mathrm{MgCl}_{2}$ のほかに, 潮解性塩化物の $\mathrm{CaCl}_{2}$ 及び $\mathrm{ZnCl}_{2}$ について 行った。Table 2 は, 実験に用いた人工海水の組成を示 す。塩化物単独の溶液の濃度は, 付着 $\mathrm{Cl}$ 量をそろえる ため, 0.5 規定濃度とした。 $\mathrm{ZnCl}_{2}$ 溶液は, 試薬を溶解

Table 2 Composition of synthetic sea water.

\begin{tabular}{lr}
\hline Chemicals & $\mathrm{g} / 1$ \\
\hline $\mathrm{NaCl}$ & 27.26 \\
$\mathrm{MgCl}$ & 3.51 \\
$\mathrm{KCl}$ & 0.69 \\
$\mathrm{KBr}$ & 0.09 \\
$\mathrm{MgSO}$ & 1.84 \\
$\mathrm{CaSO}_{4}$ & 1.29 \\
$\mathrm{NaHCO}_{3}$ & 0.11 \\
\hline \hline pH was ajusted to 8.1 \\
\hline
\end{tabular}

したままでは白色コロイド状沈でんが生じるので， pH 4.5 になるまで $\mathrm{HCl}$ を加兄て，透明な溶液にして用い た。滴下溶液の濃度と滴下液量及び塩化物スポットの面 積から計算した見かけの付着塩量は, 人工海水では 13.9
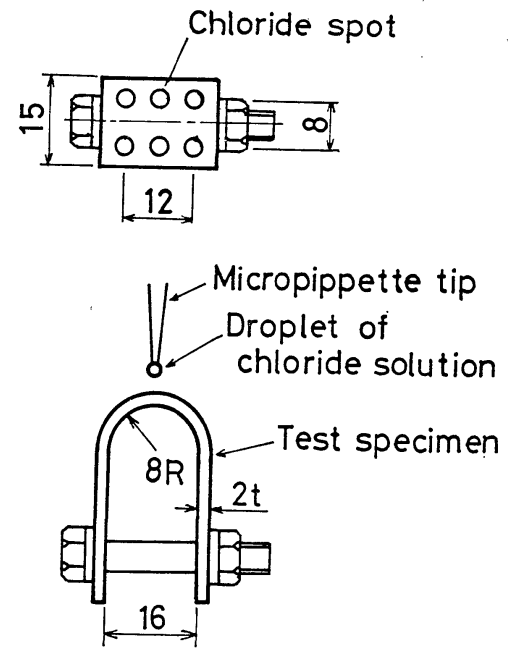

Fig. 1 Details of U-bend specimen and technique procedure of depositting droplet of chloride solution.

$\mu \mathrm{g} / \mathrm{mm}^{2}$ as $\mathrm{Cl}$, これ以外の塩化物では $12.7 \mu \mathrm{g} / \mathrm{mm}^{2}$ as $\mathrm{Cl}$ である。

Fig. 1 は試験片の形状を示す。Uベンド試験片 $\mathrm{R}$ 部 の 6 箇所飞塩化物溶液 $5 \mu 1$ を滴下し, 自然乾燥後, $\mathrm{R}$ 部を上に向けて恒温恒湿雲囲気中で 2 週間 $(336 \mathrm{~h}, 1.21$ $\left.\times 10^{6} \mathrm{sec}\right)$ 腐食試験した。試験片は各条件 2 個ずつ用 い, 試験温度は $50^{\circ} \mathrm{C}\left(323^{\circ} \mathrm{K}\right)$ 及び $70^{\circ} \mathrm{C}\left(343^{\circ} \mathrm{K}\right)$ と した。恒温恒湿試験は, 大部分を恒温恒湿槽で行った が，一部は液体調湿法 ${ }^{5)}$,6)を用いた。

なお，試験片材料は市販受入れ材そのまをを用い，固 溶化等の熱処理を行っていないが，平板のままで塩化物 スポット法によるSCC 試験をした結果では割れは生じ なかった。

\section{2 割れの評価}

試験終了後, 試験片に付着している塩化物を水洗で除 去し, 試験片の脚間隔を $14 \mathrm{~mm}$ に狭めて割れを開き, 試験片表面の割れ発生状況を倍率 10 60 倍の光学顕微 鏡による観察で調べた。Fig. 2 は割れ発生状況の例 を示す。眓は試験片表面の塩化物やさびを除さ，割れを 開いた状態である。眓の中央部に円い塩化物スポットの 跡が見られ，割れはスポットの外まで伸びている。割れ の発生状況を定量的に評価するため, 塩化物スポット個 々について割れ発生の有無, 割れの数及び最も大きい割 れの長さを調べ，これらの值から下式により割れ発生率 $\left(R_{\text {crack }}\right)$, 割れ数の平均 $\left(N_{\text {mean }}\right)$ 及び最大割れ長さの 平均 $\left(L_{\text {mean }}\right)$ を求めた。 $R_{\text {crack }}, N_{\text {mean }}$ は割れの発生頻 度を， $L_{\text {mean }}$ は割れ進展の速さを示す指標である。これ らの值が大きいほど割れ感受性が高いと評価する。

$$
R_{\text {crack }}(\%)=b / a \times 100
$$






Fig. 2 An example of cracked specimen surface in as-received SUS 304 contact with synthetic sea water after 2 weeks at $70^{\circ} \mathrm{C}$ with $30 \% \mathrm{RH}$.

$$
\begin{aligned}
& N_{\text {mean }}=c / b \\
& L_{\text {mean }}(\mathrm{mm})-d / b
\end{aligned}
$$

$a$ : 試跧した塩化物スポットの数 $(=12)$

$b$ : 割れが発生した塩化物スポットの数

$c$ : 割れの数の総和

$d$ : 各塩化物スポットにおける最大割れ長さの和 な拉， $L_{\text {mean }}$ や $N_{\text {mean }}$ の算出に $b$ 值を用いたのは次 のような理由による。本報の実験では，例方ば $\mathrm{MgCl}_{2}$ 存在下に拈讨る SUS 304 の $70^{\circ} \mathrm{C}, 90 \% \mathrm{RH}$ (RH：相 対湿度) のデータのように， $R_{\text {crack }}$ が小さいのにかなり 大きな割れが生じることがある。このような場合に $L_{\text {mear }}$ 式の分母K $a$ 值を用いると， $L_{\text {mean }}$ の值が実際 に生じた㓶れの大きさよりも極端に小さな値に算出され てしまうので，b 值を用いることにした。 $N_{\text {mean }}$ も $L_{\text {man }}$ と同様な算出方法とした。 $b$ 值で算出した方法 が, 割れ発生の状況が具体的に表現されていると思われ る。

\section{3. 実験結果及びその検討}

Fig. 3〜7 は, 割れの湿度依存性を調べた実験結果を 示す。 $L_{\text {mean }}, N_{\text {mean }}$ 及び $R_{\text {erack }}$ とも湿度によって大き く変化し，塩化物存在下に打引るステンレス鋼の大気腐 食割れには湿度が大きく影響することが明らかである。 そして， $L_{\text {mean }}$ が大きい湿度では $N_{\text {mean }}$ や $R_{\text {crack }}$ す 大きい傾向にあり，割れの発生率が高い条件では成長も 速いであろうことがうかがわれる。割れの発生過程と成 長過程を包含した值と考えられる $L_{\text {mean }}$ で判断すると, 各塩化物長過程を包について最も割れ易い湿度 $\left(\mathrm{RH}_{\mathrm{max}}\right)$ が存在し，これより高い湿度領域では高湿度ほど割れに くくなる。 $\mathrm{RH}_{\max }$ よりかなり低い限界湿度 $\left(\mathrm{RH}_{\mathrm{crit}}\right)$ 以

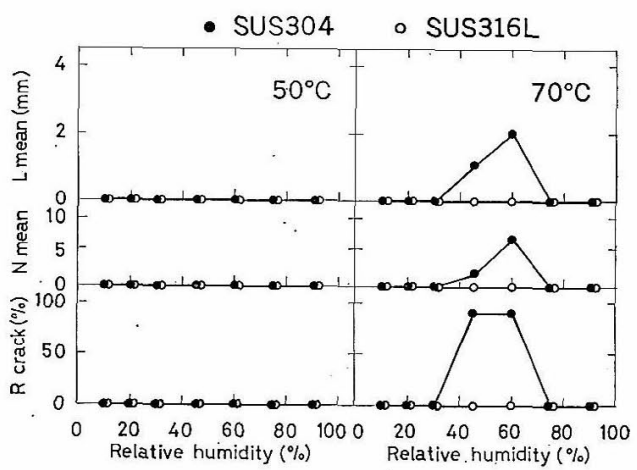

Fig. 3 Effects of relative humidity and temperature on the atmospheric SCC of stainless steels contact with $\mathrm{NaCl}$ solution.

$R_{\text {eracks }}$ : the ratio of number of chloride spots with cracks to number of tested chloride spots. $N_{\text {mean }}$ : mean number of cracks in chloride spots with cracks. $L$ mean : mean length of the largest crack in chloride spots with cracks.

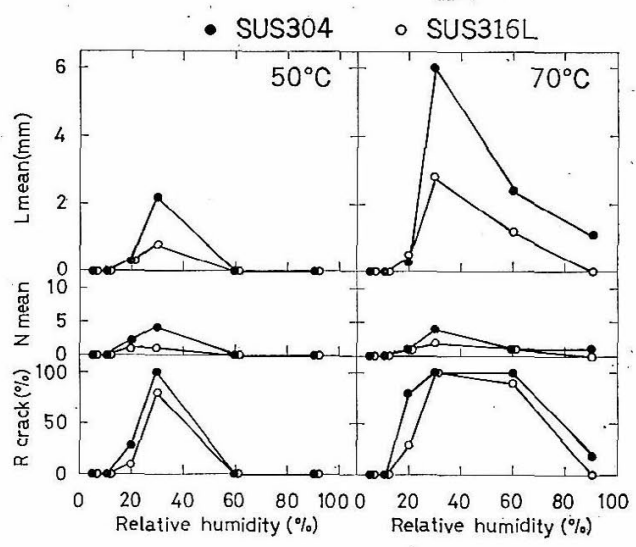

Fig. 4 Effects of relative humidity and temperature on the atmospheric SCC of stainless steels contact with $\mathrm{MgCl}_{2}$ solution.

See Fig. 3 for $R_{\text {erack }}, N_{\text {mean }}$ and $L$ mean.

下では割れが生じない。な㧍，高い湿度で割れにくくな


結果7でも認められている。

Fig. 8 は，SUS 304 の割れの断面観察結果の例を示 す。割れは典形的な貫粒型割れ (TGSCC) である。 316L も同様な TGSCC であった。割れ発生部表面の観 察によると，割れには常に孔食が伴っているので，割れ は孔食を起点としていると判断された。

人工海水による割れの湿度依存性 (Fig. 7) は, 海水 主成分の $\mathrm{NaCl}$ の湿度依存性 (Fig. 3) よりも, 副成分 $\mathrm{MgCl}_{2}$ (Fig. 4) のそれに類似しているので, 海水の割 れ発生作用（割れを生じさせる性質の意）は， $\mathrm{MgCl}_{2}$ に 




Fig. 5 Effects of relative humidity and temperature on the atmospheric SCC of stainless steels contact with $\mathrm{CaCl}_{2}$ solution.

See Fig. 3 for $\mathbf{R}$ crack, $\mathbf{N}$ mean and $\mathbf{L}$ mean.

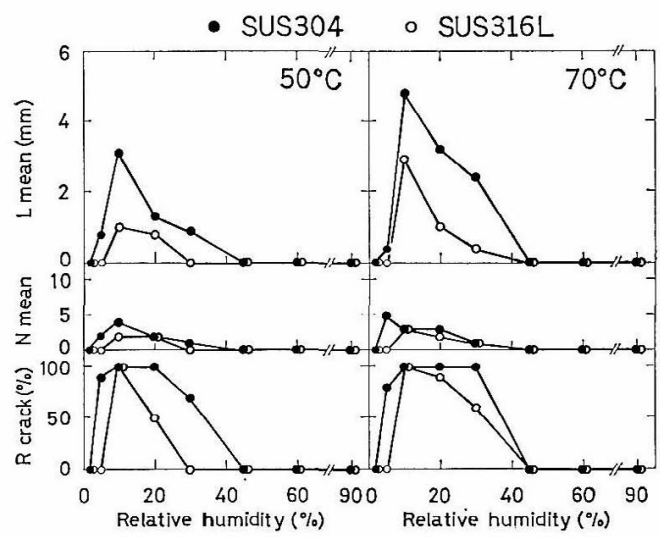

Fig. 6 Effects of relative humidity and temperature on the atmospheric SCC of stainless steels contact with $\mathrm{ZnCl}_{2}$ solution.

See Fig. 3 for $\mathrm{R}$ crack, $\mathrm{N}$ mean and $\mathrm{L}$ mean.

支配されているとい党る。大気腐食割れの特徽のひとつ であろら。

SUS 316L の割れの湿度依存性は 304 と同様である が，316L の割れ感受性はいずれの塩化物でも 304 より 低い。316L は溶接による粒界鋭敏化が起こりにくい材 質として着日されているが，本実験結果から，非鋭敏化 状態での塩化物大気腐食割れに対する耐食性も304より 優れているといえる。割れが孔食起点型なので，Moの 添加等によって耐孔食性が高められていることが寄与し ていると思われる。

金属表面に吸湿性物質が付着すると腐食発生下限界湿 度が低下するといら考え力は従来よりなされている゙が， 割れ発生湿度領域の比較的低い湿度に $\mathrm{RH}_{\max }$ が現われ

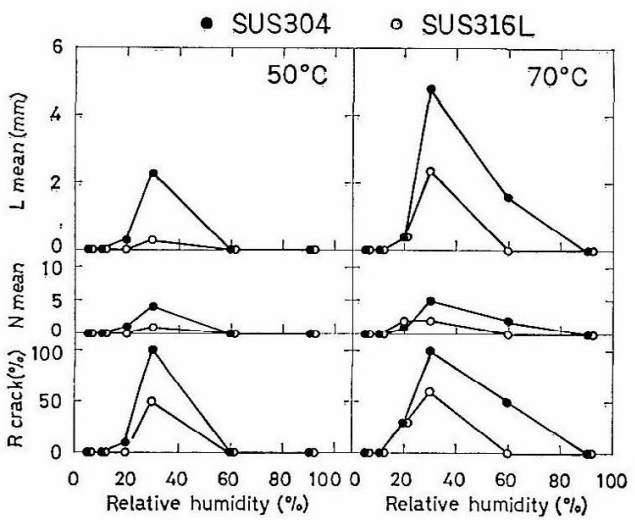

Fig. 7 Effects of relative humidity and temperature on the atmospheric SCC of stainless steels contact with synthetic sea water.

See Fig. 3 for $\mathrm{R}$ crack, $\mathrm{N}$ mean and $\mathrm{L}$ mean.

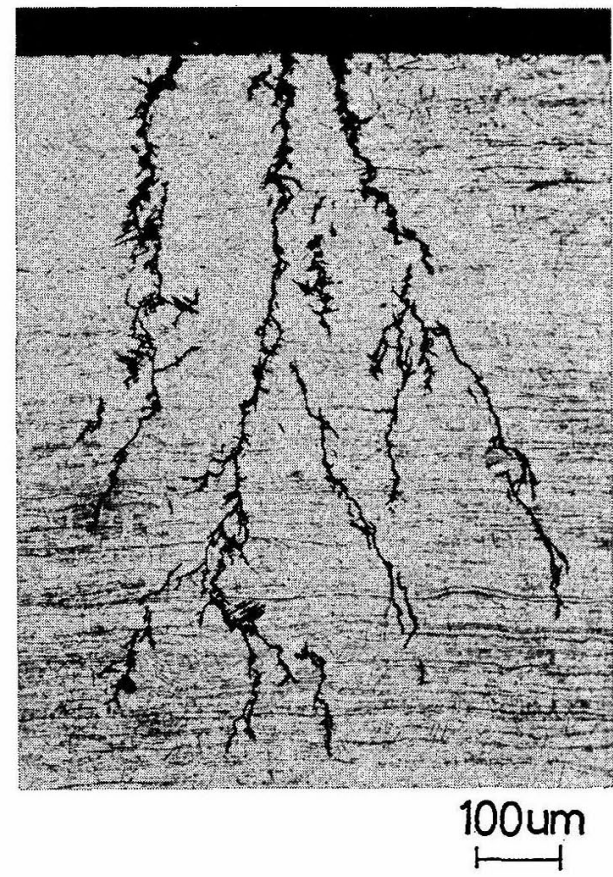

Fig. 8 Typical TGSCC observed in as-received SUS 304 contact with synthetic sea water after 2 weeks at $70^{\circ} \mathrm{C}$ with $30 \% \mathrm{RH}$.

ること，海水の割れ発生作用が $\mathrm{MgCl}_{2}$ に支配されるこ と等は新しい知見といえる。

\section{4. 考察}

\section{1 割れの湿度依存性}

それぞれの塩化物で， $\mathrm{RH}_{\max }$ は $50^{\circ} \mathrm{C}$ と $70^{\circ} \mathrm{C}$ でほ ぼ同じ值である。従って, 塩化物存在下の大気腐食割れ は相対湿度に支配されているといえる。仮に, 絶対湿度 


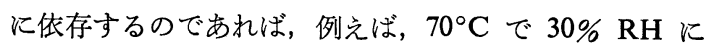
$\mathrm{RH}_{\max }$ のある $\mathrm{MgCl}_{2}$ においては, $50^{\circ} \mathrm{C}$ では $72 \% \mathrm{RH}$ に $\mathrm{RH}_{\max }$ が現われなければならない計算になる。相対 湿度に依存するのは，次に述べるように，塩化物の割れ 発生作用が塩化物の吸湿性と密接に関係するためと考兄 られる。

まず，塩化物固有の湿度に $\mathrm{RH}_{\max }$ が現われる理由を 考える (人工海水の割れ発生作用が $\mathrm{MgCl}_{2}$ 支配である 点に関しては後述)。本報で取上げた温度での腐食には 液体の水あるいは溶液の存在が不可欠之考兄られるの で, 割れが発生するような湿度では, スポットの塩化物 は飽和までの濃度の溶液あるいは飽和溶液と固相 (結晶) が共存した状態にあるはずである。そして, 塩化物溶液 の割れ発生作用は濃度に依存し, その濃度は䨌囲気の湿 度と平衡にあると考兄られる。従って, 各塩化物につい て濃度と平衡湿度あるいは水蒸気圧の関係を示すデータ があれば，割れの湿度依存性を理解するのは比較的容易 であろらが，この目的にかならデータや関係式は見あた らない (溶液濃度と蒸気圧の関係式として Raoult's law があるが，これで計算した值は実測值と一致しないこと が多( $\left.{ }^{9)}\right)$ 。しかし, 飽和溶液と平衡にある湿度につい ては, 固相共存飽和溶液上の密閉空間の湿度として, 塩 類による湿度調節や湿度定点の観点から，かなり多くの 化合物について求められている5，6) ので, この值（以下 では飽和溶液平衡湿度 $P_{\text {sat }}$ と呼ぶ）をよりどころに して考察を進める。Fig. 9 は, 割れ試験に用いた塩化 物の $P_{\mathrm{sat}}^{5), 6)}$ を示す。Fig. 10 は各塩化物の $\mathrm{RH}_{\mathrm{max}}$ と $P_{\text {sat }}$ の関係を示したもので, $\mathrm{RH}_{\max }$ と $P_{\text {sat }}$ はかな り良く一致している。このことと潮解現象の考兄方を結 びつけると, 次のよう考光られる。即ち， $P_{\mathrm{sat}}$ に近

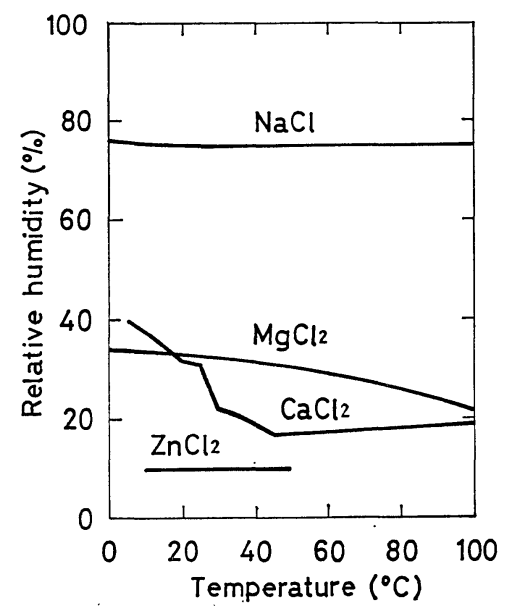

Fig. 9 Equilibrium relative humidity $\left(P_{\text {sat }}\right)$ temperature relationships of saturated chloride solutions.



Fig. 10 Corresponding to $P_{\text {sat }}$ of $\mathrm{RH}_{\text {max }}$.

い雲囲気では塩化物スポットには飽和溶液あるいはこれ に近い高濃度の液膜が形成されるので割れが生じやす く, 高湿度雾囲気では液膜の塩化物濃度が低くなるため に割れにくくなる。

$\mathrm{RH}_{\max }$ より高い湿度では湿度の増加と共に割れ発生 作用が弱くなると述べたが，これは腐食作用が消失する という意味ではなく，割れ発生までに長時間かかるとい ら意味である。このことは $50^{\circ} \mathrm{C}$ と $70^{\circ} \mathrm{C}$ のデータの 比較検討から推察される。7 $0^{\circ} \mathrm{C}$ に拈ける割れの湿度依 存曲線は, $50^{\circ} \mathrm{C}$ の曲線を図の上方に移動したものと見 ることが可能で, $50^{\circ} \mathrm{C}$ から $70^{\circ} \mathrm{C}$ への温度の上昇を反 応速度の増加とすれば, $70^{\circ} \mathrm{C}$ のデータは $50^{\circ} \mathrm{C}$ の長時 間側のデータと見なせる。従って, 高湿度条件に捻いて も長時間かければ割れる可能性がある。

本報の実験範囲外の温度での湿度依存性については, Fig. 9 に示した $P_{\mathrm{sat}}$ の温度変化曲線から推定できる。 $\mathrm{NaCl}$ や $\mathrm{ZnCl}_{2}$ 存在下では $\mathrm{RH}_{\max }$ が温度でほとんど 変化しないが， $\mathrm{MgCl}_{2}$ では小さな温度変化を示し， $\mathrm{CaCl}_{2}$ では低い温度領域でやや複雑に変化するである 万。

第 3 章で述べたように, 海水の割れ発生作用は $\mathrm{MgCl}_{2}$ に支配されている。 $\mathrm{NaCl}$ と $\mathrm{MgCl}_{2}$ の混合系の水に対 する溶解度 ${ }^{10}$ や, 海水の濃縮過程で析出する固体成分 ${ }^{11)}$ から推察すると，30\% RH では海水中の $\mathrm{NaCl}$ は結晶 として析出するが， $\mathrm{MgCl}_{2}$ は溶液として存在し得るた めに, $\mathrm{MgCl}_{2}$ 支配になったと考㝋られる。

\section{2 割れ発生下限界湿度}

$\mathrm{RH}_{\max }$ より低い湿度領域に着目する。割れなくなる 湿度 $\left(\mathrm{RH}_{\mathrm{crit}}\right)$ は $\mathrm{RH}_{\max }$ よりもかなり低い值である。 例总ば, $\mathrm{RH}_{\max }$ が $30 \% \mathrm{RH}$ の $\mathrm{MgCl}_{2}$ では, $20 \% \mathrm{RH}$ 付近以下の湿度で割れれなくなる。この実験事実に対し て, 表面的には, 腐食に関与寸る水の無くなる湿度が $20 \% \mathrm{RH}$ 付近以下であると説明でさる。しかしながら， 潮解や風解の基本的考方方によれば，溶液は $P_{\mathrm{sat}}$ より 
わずかに低い湿度でも乾涸あるいは風解する方向なの で, $P_{\text {sat }}$ が $30 \% \mathrm{RH}$ である $\mathrm{MgCl}_{2}$ の $\mathrm{RH}_{\text {crit }}$ は $30 \%$ RH より若干低い值でよいはずである。 $\mathrm{RH}_{\text {crit }}$ が $P_{\text {sat }}$ よりもかなり低い湿度である理由を理解するには，他の 現象を考兄る必要があうう。金属表面への固体（塩化物 結晶）の付着は毛管凝縮作用を促すので，まずこれが関 与するであろらが，毛管作用に係らない物理吸着が寄与 する可能性もある。物理吸着は，多分子層吸着が可能 で, 水分の飽和蒸気圧のところで㠜縮之連続的につなが


吸着も関与するといら考方方はかなり妥当と思われる。

Fig. 10 に示されているように, $\mathrm{NaCl}$ 以外の塩化物 では $P_{\text {sat }}$ と $\mathrm{RH}_{\max }$ はよく一致しているのに対して, $\mathrm{NaCl}$ 存在下では $P_{\mathrm{sat}}$ と等しい湿度に扔けるよりも若 干低い湿度での方が割れやすい。この湿度領域では，多 量の結晶と毛管作用や物理吸着によって形成される微量 の飽和溶液が共存している状態で, 液膜の量や厚さ, 局 所的分布等が割れ発生作用を支配している領域ではない かと思われる。

\section{3 塩化物の種類と腐食性}

$\mathrm{NaCl}$ 存在下では $70^{\circ} \mathrm{C}$ で SUS 304 のみが割れてい るのに対して, $\mathrm{MgCl}_{2}$ や $\mathrm{CaCl}_{2}$ では $50^{\circ} \mathrm{C}$ で $316 \mathrm{~L}$ も割れているので, 割れ発生作用は $\mathrm{NaCl} よ り も ~ \mathrm{MgCl}_{2}$ や $\mathrm{CaCl}_{2}$ の方が強いと判断できる。 $\mathrm{RH}_{\max }$ に括ける $L_{\text {mean }}$ で比較すると, $\mathrm{MgCl}_{2}$ よりも $\mathrm{CaCl}_{2}$ 存在下での 方が割れやすい傾向にある。このように塩化物の種類に よって割れ発生作用に差が生じる理由として, 湿度依存 性に対する解釈と同様に, 液膜の $\mathrm{Cl}$ 濃度を考学ること ができるであるう。

$\mathrm{RH}_{\max }$ 付近では塩化物の 液膜は飽和濃度ないしこれ 飞近い濃度になっていると考えられるので， $\mathrm{NaCl}$ ， $\mathrm{MgCl}_{2}, \mathrm{CaCl}_{2}, \mathrm{ZnCl}_{2}$ について $70^{\circ} \mathrm{C}$ の飽和濃度を調 べてみると 17，29，38 及び $44 \mathrm{wt} \%$ as $\mathrm{Cl}$ である。飽 和 $\mathrm{Cl}$ 濃度の序列と割れ発生作用強さの序列は注ぼ一致 している。

割㣗発生作用の強さは, 塩化物液膜の $\mathrm{pH}$ や孔食発 生作用, 腐食に伴亏液質の変化, 塩化物自身の大気中に おケる安定性等が複雑泎用する総合的結果であるら が，基本的には $\mathrm{Cl}$ 濃度が支配する可能性が強い。

\section{4 海塩粒子存在下における防食湿度}

本報の実験は, 試験片表面に多量の塩化物を付着させ た状態での定湿度試験なので, 降雨のたびに可溶性塩化 物が洗い流される屋外大気ばくろ状態に比べれば，かな り苛酷な加速試験であることを否定できない。しかしな がら, 人工海水のデータは, 海塩粒子が付着した状態で 長期間使用されるステンレス鋼の大気腐食割れに対する 湿度依存性が端的に表われていると思われる。
人工海水による割れは $20 \% \mathrm{RH}$ 付近以下では発生し ないので，これより低い湿度を保てば恒久的に防食され るであろう。そして, 塩化物存在下の大気腐食割れが付 着塩化物の吸湿性いわば化学凝縮に基づく現象である点 に着目すれば，防食湿度は塩化物付着表面に打ける相対 湿度で達成されるべきと考えられる。

なお，実験結果に記したように，割れには常に孔食が 伴っている。割れの観察で得た経験によると, 割れに伴 っている孔食の大きさ（表面観察に上る大きさ）は，高 湿度条件でょりも，比較的低い湿度（液膜の塩化物濃度 が飽和濃度に近い）での方が小さい傾向が見られた。割 にれに移行する孔食限界大きさあるいは孔食の発生や成 長対する湿度依存性など今後解明して行く必要がある。 本報では，孔食と割れを区別することなく，大気腐食割 れに対する湿度の影響に関した基本的データの把握とそ の化学的解釈に重点を置いた。

\section{5. 結 論}

海塩粒子等の塩化物存在下に括汸るステンレス鋼の大 気腐食割れに対する湿度の影響を, 実験室的に調べた結 果，次のことが明らかになった。

（1）塩化物存在下の大気腐食割れには，湿度が大き な影響を及ぼす。そして，塩化物の種類により，それぞ れ固有の湿度で最も割れやすく $\left(\mathrm{RH}_{\max }\right)$, これより高湿 度では割れにくくなる。この現象は塩化物の吸湿性に基 ゔく液膜の塩化物濃度の差により生じるもので, $\mathrm{RH}_{\max }$ 付近では飽和溶液あるいは飽和溶液と結晶の混合液膜が 形成され，高湿度では濃度の低い液膜が形成されると考 えられる。

（2）割れが発生しなくなる湿度 $\left(\mathrm{RH}_{\mathrm{crit}}\right)$ は， $\mathrm{RH}_{\max }$ よりもかなり低い值である。

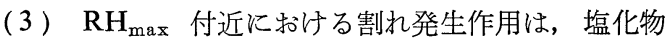
の種類で異なる。 $\mathrm{RH}_{\max }$ 付近で形成される液膜の塩化 物濃度が，塩化物の種類により異なることが基本的な因 子と考兄られる。

（4）海水の割れ 発生作用は $\mathrm{MgCl}_{2}$ に支配され, $\mathrm{RH}_{\max }$ は $30 \% \mathrm{RH}$ 付近である。海水存在下の防食湿 度は $20 \% \mathrm{RH}$ 付近以下である。

終りに，本研究に関して種々のご討論やご指導を頂い た (株) 日立製作所日立工場 伊藤久雄専門副技師長に深 く感謝致します。

(Received April 16, 1986)

\section{文献}

1）大久保勝夫：防食技術，30, 705 (1981)。

2) 中村寿和，山本勝美，賀川直彦：防食技術，34， 346 (1985).

3) M. Takemoto, T. Shonohara, M. Shirai \& 
T. Shinogaya: Materials Performance, 24, 26 (June 1985)

4) 庄司三郎, 大中紀之, 菊池英二, 湊 昭, 丹野 和夫: 防食技術, 29, 323 (1980).

5) 高分子学会編：材料と水分ハンドブック，p. 240, 共立出版 (昭 43).

6) L. Greenspan: J. Res. N.B.S., 81A, 89 (1977).

7) M. Yajima, M. Arii: Materials Performance, 19, 17 (Dec. 1980).

8) N.D. Tomashov: Theory of Corrosion and
Protection of Metals, p. 367, Macmillan Co. (1966).

9）佐藤 靖：防錆防食塗装技術, p. 72, 工学図書 (昭 56).

10）日本化学会編：化学便覽，基礎編 II, p. 798，九 善 (昭 55).

11）永井彰一郎：海水化学， p. 81 , 日刊工業新聞社 (昭 38),

12）D. J. Shaw (北原, 青木訳)：コロイドと界面の 化学, p. 99, 広川書店 (昭 42). 